\title{
An Alternative Funding Model for Agribusiness Research in Canada
}

\author{
Adam Dale ${ }^{1}$, Elliott Currie ${ }^{2}$ \\ ${ }^{1}$ Department of Plant Agriculture, University of Guelph, Simcoe Research Station, Simcoe, Canada \\ ${ }^{2}$ Department of Management, University of Guelph, Guelph, Canada \\ Email: adale@uoguelph.ca, ecurrie@uoguelph.ca
}

Received 12 August 2015; accepted 15 September 2015; published 21 September 2015

Copyright (C) 2015 by authors and Scientific Research Publishing Inc.

This work is licensed under the Creative Commons Attribution International License (CC BY).

http://creativecommons.org/licenses/by/4.0/

(c) (i) Open Access

\begin{abstract}
Canadian governments have moved towards a matching funding model for agricultural research. Agricultural organizations can take advantage of this if Canadian Controlled Private Corporations are established to fund research through matching grants, tax credits and investments. A low risk options strategy is presented which uses index options and is a diagonal put spread where an in-the-money put is bought which expires in 1 to 2 years and out-of-the-money puts are sold which expire monthly. In summary, "A small Canadian Controlled Private Corporation can, for a $\$ \mathbf{1 0 0 , 0 0 0}$ up front initial investment, generate at least $\$ \mathbf{1 0 0 , 0 0 0}$ annually in research funding, in perpetuity".
\end{abstract}

Keywords

Tax Credits, Index Options, Research Funding, Capital Gains, Matching Funds

\section{Introduction}

Over the last twenty years, there has been increasingly less funding given to applied or near-market agricultural research in Ontario. In 2009 the total research and development expenditures by business enterprises in food manufacturing was tabulated by Agriculture and Agri-Food Canada at $\$ 157$ million and was planned to grow to only $\$ 172$ million by 2014 . This reflects a growth rate of less than $2 \%$ per year, marginally matching inflation [1] [2]. Also, The Ontario Ministry of Agriculture and Food and Rural Affairs entered into a 5-year agreement with the University of Guelph to fund research. 57 million dollars was to be transferred to the university annually with no inflation factor to be applied [3].

There have been many reasons for this: governments have moved to a matching funding model, commodity prices have remained low and the agricultural industry has traditionally relied on government funding for re- 
search. The move to matching funding models was, in part, because in the 1990s the Canadian and Provincial governments discovered that agricultural businesses were contributing less to gross expenditures on research and development as a proportion of GDP than their counterparts in other OECD counties, whereas government funding was greater than most [4].

Governments in Canada now encourage private organizations and industry groups to invest in agricultural research through matching funds and tax credits. However, these could be used more if agricultural organizations would have consistent access to more capital for research within their organizations.

Also, the present agenda for agricultural research is driven largely by government who provides almost all the funding for public research. This sometimes causes conflict as government agendas may differ from those of the industry. However, governments have made great efforts to involve industry in priority setting, and now release funds through agencies such as the Adaptation Councils for the industry to control. In Ontario, the Ontario Ministry of Food and Rural Affairs has a priority setting process which involves industry, academia, government, and public stakeholders. Through a process of Expert Panels and Theme Advisory Groups priorities for seven research themes are obtained [5].

Within crop agriculture, which is largely not supply managed, there are many crops with diverse acreages and values. In Ontario, the field crops contribute by far the largest acreage, somewhat similar farm gate values and the fewest crops compared to the other crops. Horticultural crops contribute to many high value crops often grown on very few hectares (Table 1).

The research model proposed has the potential to provide long-term, stable research funding for agricultural organizations. This model is applicable to large agribusiness corporations. However, the examples used will be applicable to small horticultural producers because they are usually small individual operations, defined as less than 200 acres. This paper suggests an organizational model which then uses three funding streams to provide the research funding. The three funding streams are grants, tax credits, and capital markets

While matching grant and tax credits are well researched, less effort has been put into generating the initial organizational funding. Here an innovative approach is suggested to find the initial "cash" needed to obtain the matching funding.

The essence of the research funding model can be encapsulated in the statement "A small Canadian Controlled Private Corporation (CСC) can, for a $\$ 100,000$ up front initial investment, generate at least $\$ 100,000$ annually in research funding, in perpetuity".

\section{Governance Model}

There are three possible organizational structures that can be used: a private corporation, a co-operative and a not-for-profit corporation (Table 2). Agricultural examples of these exist in Ontario.

A small, for-profit, Canadian Controlled Private Corporation (CCPC) is defined as a corporation with less than $\$ 500,000$ in taxable income, and less than $\$ 15$ million taxable capital. Also, it is limited to no more than fifty individual shareholders and cannot be controlled by or related to a foreign corporation or individual [6]. This type of organization is not restricted in the lawful activities it may engage in to make a profit. It pays tax on income generated from all sources. Tax credits are available to it in a number of fields as provided by various levels of government. Dividends may be distributed to shareholders at the corporation's discretion.

Co-operatives are also permitted to conduct many of the same undertakings as for-profit corporations. However, they may be limited in their investment activities by their Articles of Incorporation, and the overall intent

Table 1. Estimated hectares, crop value and crop number for major crop groups in Ontario in 2010 (OMAFRA, 2011).

\begin{tabular}{cccc}
\hline & Hectares & \$ Million & Number \\
\hline Field crops & $3,400,000$ & 2100 & 13 \\
Field vegetables & 71,000 & 530 & 32 \\
Fruit & 25,000 & 220 & 16 \\
Greenhouse vegetables & 650 & 530 & 4 \\
Greenhouse ornamentals & 460 & 742 & 31 \\
\hline
\end{tabular}

Crop value for field crops only includes soybeans, corn, and wheat. 
Table 2. Advantages and disadvantages of different governance models for the agribusiness research in Canada.

\begin{tabular}{|c|c|c|}
\hline Governance model & Advantages & Disadvantages \\
\hline Private Corporation & $\begin{array}{l}\text { 1) Virtually unlimited activities } \\
\text { 2) Dividends payable from profits } \\
\text { 3) Various persons can be shareholders } \\
\text { 4) Tax credits available } \\
\text { 5) Shareholders have limited liability } \\
\text { 6) Unlimited life } \\
\text { 7) Ability to raise financing }\end{array}$ & $\begin{array}{l}\text { 1) Complex taxation system } \\
\text { 2) Small business credits limited to } \\
\text { related entities of limiting profits and } \\
\text { assets. }\end{array}$ \\
\hline Cooperative & $\begin{array}{l}\text { 1) Ease of establishment by order of } \\
\text { government } \\
\text { 2) Unlimited life }\end{array}$ & $\begin{array}{l}\text { 1) Limited activities by order of Articles } \\
\text { of Incorporation } \\
\text { 2) May not be able to distribute profits to } \\
\text { members } \\
\text { 3) All members have input to } \\
\text { management } \\
\text { 4) Limited equity investment }\end{array}$ \\
\hline Not-for-profit & $\begin{array}{l}\text { 1) Harder to incorporate than previous } \\
\text { two, re-quires approval from govern- } \\
\text { ment } \\
\text { 2) No taxes paid } \\
\text { 3) Unlimited life }\end{array}$ & $\begin{array}{l}\text { 1) Not able to access tax credits } \\
\text { 2) No distribution of profits } \\
\text { 3) Stringent government scrutiny due to } \\
\text { not-for-profit status } \\
\text { 4) Limited revenue generating activities }\end{array}$ \\
\hline
\end{tabular}

of their incorporation. Generally the co-operative is to function in the best interests and on behalf of its members. Management may be an issue as each member of the co-operative has an equal vote and membership is limited to small producers or persons with a common bond. Hence other members of the value chain may not be able to join and contribute to the management and direction of the co-operative [7]. In some co-operatives it is possible to pass some profits through to members as a patronage payment if this is laid out in the articles of incorporation. As the co-op does pay taxes it can access corresponding tax credits for various activities including those described below, but limited to the mandate of the Articles of Incorporation as approved by the government granting the co-operative status.

Not-for-profit corporations are by their very name, denied the ability to distribute their surpluses (profits) to their shareholders [8]. However, not-for-profit corporations are permitted to undertake all the same activities as a for-profit corporation and may own a for-profit corporation. They are also not limited in their ability to accept different shareholders. The major criteria for their existence, which are in their articles of incorporation, require that the entity serve purposes which benefit the shareholders or community but do not generate profit. This form of corporation, being nontaxable, excludes it from claiming tax credits and in this case, on research. However the tax credits may be used by a wholly owned subsidiary to offset profits or income generated by other activities.

So the suggested governance model is a Holding Corporation (co-op or for profit) which owns at least two CCPCs, one for investment and research, and one for operations. The purpose of the Holding Corporation would be to invest in capital markets, service, process, market and research horticultural products and their value chain. By merging the various activities, the tax credits from two levels of government can be accessed, the range of membership can be expanded to include the whole value chain, and when available, profits can be distributed to the shareholders or members.

Legally, a for-profit corporation can earn income, and invest in research or income generating assets more easily. Also, it permits investors from all parts of the value chain and other interested parties to own shares in the corporation. When the primary functions of the corporation are separated, the research tax credits can be offset against investment income while the Operational subsidiary focuses on directly serving the industry that owns the Holding Corporation.

\section{Funding}

\subsection{General Process}

Traditionally, agricultural research is funded in two ways: directly by government and through producer groups 
or similar associations who apply to Federal or Provincial research funding bodies, with a small cash contribution.

Recently the Canadian and Provincial governments have raised the amount agricultural groups need to contribute (match) to $50 \%$ of a research proposal from $15 \%$ to $20 \%$. This includes both operating funds and the funds to employ the scientists.

In the past, most research applicants approached their members or stakeholders for annual and or multi-year cash contributions and commitments. With the increased portion of funding needed by the producer groups, this demand is becoming much larger. As a result, it has become challenging for producer groups to find the funds as their members either do not have the cash, are reluctant to fund research projects which take a long time to complete, or which they do not understand.

\subsection{Matching Grants}

There are matching grants or contracts available which can provide up to half or three-quarters of the eligible funding for Scientific Research and Experimental Development (SR\&ED) projects to agricultural entities. Some of these funds provided federally by the National Science and Engineering Research Council (NSERC) [www.nserc-crsng.gc.ca], Agricultural Adaptation Council [www.adaptcouncil.org], Agriculture and Agrifood Canada [www.agr,gc.ca], Industrial Research and Assistance Program of the National Research Council (IRAP) [www.nrc-cnrc.gc.ca/eng/ibp/irap.html], and in Ontario by the Ontario Ministry of Agriculture, Food and Rural Affairs [www.omafra.gov.on.ca], and the Ontario Centres of Excellence [www.oce-ontario.org]. Other Provinces in Canada also have their own funding mechanisms. All, these usually provide funds for $1-3$ years, against a set of priorities. This means that entities which have long-term projects need to apply repeatedly to fund those projects. Many programs are offered in partnership with both levels of government.

\subsection{Tax Credits}

Research that is conducted for a CCPC is eligible for a Federal SR\&ED investment tax credit of 35\% [9] [10]. Larger corporations are entitled to a lower tax credit of 15\% [9].

There are three different Ontario (provincial) tax credits: 20\%, 10\%, and 4.5\%, can be combined for a total of $34.5 \%$ of the research expenditures [11]. The Ontario Business Research Institute Tax Credit grants 20\% refundable credits for research with an Eligible Research Institute such as a University. The $10 \%$ refundable Ontario Innovation Tax Credit is available to all corporations that perform SR\&ED research in Ontario. Small Businesses may claim both tax credits. The Ontario Research and Development Tax Credit, a non-refundable credit of $4.5 \%$, was introduced in 2008.

Under tax laws, income is the net proceeds a person earns from an endeavour, be it employment, a business or from owning property, such as rent or interest. A capital gain is a realized profit from the sale of an asset that was not due to an enterprising effort but from the increased value of the capital asset that is realized when the asset is sold. This applies to individuals and corporations [12].

CCPC's are generally taxed at $15 \%$ on income and other corporations face a federal tax rate of $28 \%$ on income. However, capital gains realized by both a CCPC and a larger corporation are taxed on one half of the gain at the full corporate rate of $28 \%$. Individuals are also taxed at half of their individual tax rate on capital gains but may not claim SR\&ED Tax credits. For tax purposes, research expenditures are not considered part of expenditures when the net profit is calculated. Instead they are treated separately, so that all the relevant tax credits can be calculated.

\subsection{Private Capital}

After matching grants of $50 \%$ and tax credits, an agricultural entity would need to find $\$ 181,400$ annually to fund $\$ 1$ million of research. At accepted interest rates (currently 3\% in Canada), these organizations would need to hold over $\$ 6$ million to give the required funding or ask their members to generate these funds as a check-off each year.

An alternative funding model is suggested which uses the capital markets and requires only an initial investment, and can generate 30\% - 60\% each year. It uses an options strategy which works whether the stock markets are rising or falling, and relies on the fact that options which expire in a long time, lose value less rapidly than 
those which expire in a short time.

The options strategy uses index options and is a diagonal put spread where an in-the-money put is bought which expires in $11 / 2$ to 2 years, and an out-of-the-money put is sold which expires in one month. Generally the bought options have a strike price $5 \%-10 \%$ above the price of the index, whereas the sold options will vary close to the price of the index, depending on the direction of the index (Figure 1). As the market rises the strike price of the sold options increases more rapidly than the bought options as they take longer to expire. However, the bought option strike prices increase as the old ones expire and new ones are bought. This maintains the spread between the bought and sold options.

This strategy is considered low risk as income is generated during both upward and downward moves in the market. As the markets move upwards, the sold options expire worthless. The purchasers no longer need the put options as insurance. Also, the strategy is protected from large downward moves in the indexes as the bought options of the producer group increase in value, and the price received for the sold options from the purchasers increases with the increased volatility generated by a sharp move downwards, whereas their price at expiry does not change.

An actual example is given where puts were traded on the S\&P 500 index. From 13 May 2008 until 15 Dec 2011, puts were bought at intervals for a total cost of $\$ 81,289.31$. The trades started when one put had been bought. At the end of the period, 14 puts existed and the total value of the position was $\$ 293,382$, for a net gain of $\$ 212,092$, a $261 \%$ gain over 3 yrs and 7 months (Table 3). During the period of the trades, the S\&P 500 index varied 47\% between 1425 and 769 .

Index options have been used rather than stock options for two reasons: have a greater net value, and tend to be less volatile. In the US markets, the present value of the S\&P 500 index is about 1950 and the Dow Jones Industrial Average is about 16,500 , whereas stocks tend to be less than $\$ 200$. Individual companies are often bought or go bankrupt, which causes their values to be volatile, and consequently affects the continuity of their options. Whereas indexes replace declining stocks to maintain the value of the index.

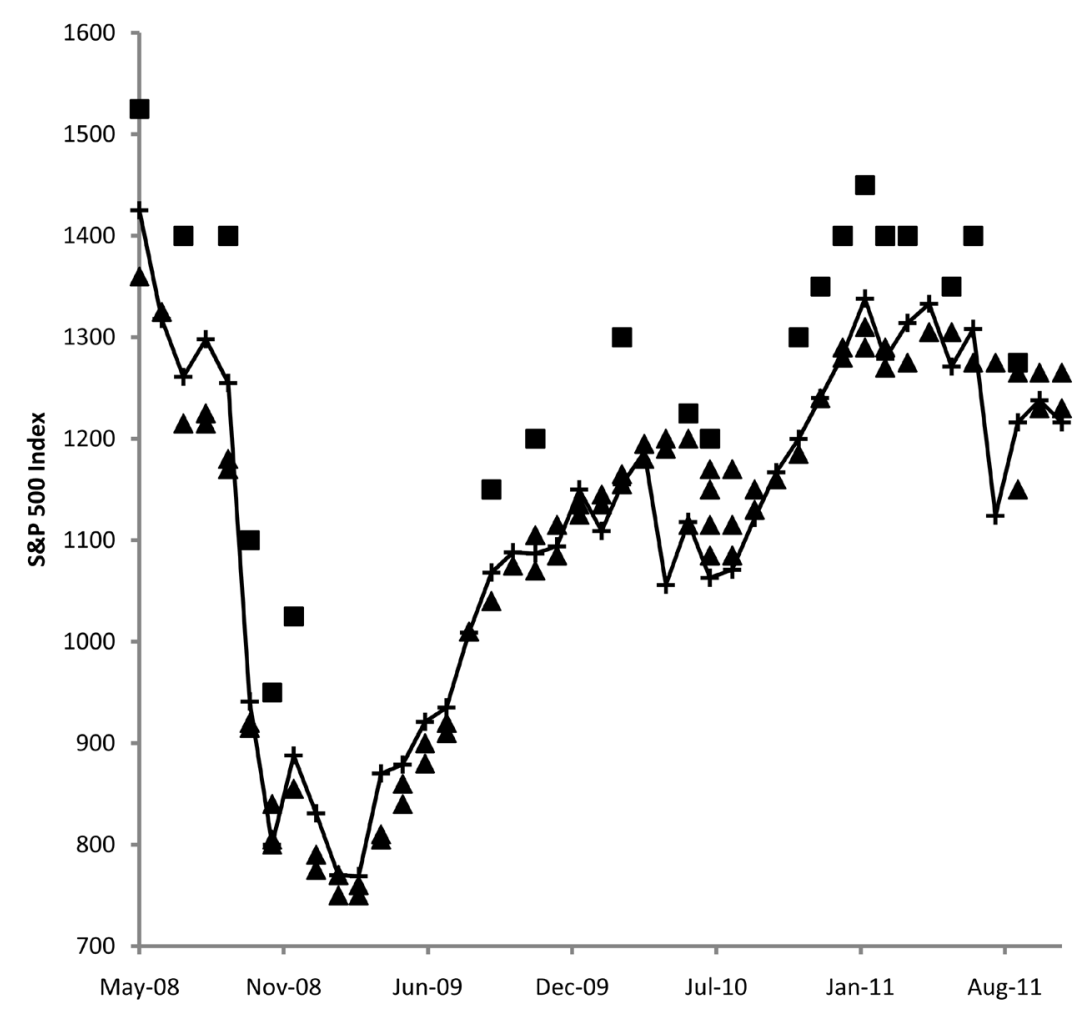

Figure 1. The strike price of S\&P500 Index options that were bought 18 - 24 months ahead $(\boldsymbol{\square})$ or sold one month ahead $(\boldsymbol{\Delta})$ together with the closing price of the S\&P500 Index $(+)$ on the $3^{\text {rd }}$ Friday of the month. The options expire on the Saturday after the $3^{\text {rd }}$ Friday of the month. 
Table 3. Investment, number of options and monthly expenses, income and net Income from an actual example where put options on the S\&P index were bought expiring 18 - 24 Months in the Future and sold expiring one month in the future from May 2008 until December 2011.

\begin{tabular}{|c|c|c|c|c|c|}
\hline Date & Investment \$ & Number of Options & Expenses \$ & Income \$ & Net Income \$ \\
\hline May 08 & 18,577 & 1 & 18,577 & 1640 & $-16,937$ \\
\hline Jun 08 & & 1 & 2111 & 3059 & 949 \\
\hline Jul 08 & & 1 & 26,862 & 29,346 & 2484 \\
\hline Aug 08 & 14,827 & 2 & 19,900 & 3749 & $-16,151$ \\
\hline Sep 08 & 21,313 & 3 & 77,572 & 58,009 & $-19,563$ \\
\hline Oct 08 & & 3 & 146,179 & 154,816 & 8636 \\
\hline Nov 08 & & 3 & 114,274 & 124,986 & 10,711 \\
\hline Dec 08 & 26,573 & 5 & 51,561 & 10,328 & $-41,233$ \\
\hline Jan 09 & & 5 & 0 & 11,892 & 11,892 \\
\hline Feb 09 & & 5 & 6480 & 16,188 & 9708 \\
\hline Mar 09 & & 5 & 0 & 9843 & 9843 \\
\hline Apr 09 & & 5 & 0 & 9498 & 9498 \\
\hline May 09 & & 5 & 0 & 9191 & 9191 \\
\hline Jun 09 & & 5 & 0 & 8796 & 8796 \\
\hline Jul 09 & & 5 & 0 & 8843 & 8843 \\
\hline Aug 09 & & 5 & 0 & 7972 & 7972 \\
\hline Sep 09 & & 6 & 21,400 & 10,205 & $-11,195$ \\
\hline Oct 09 & & 6 & 0 & 12,501 & 12,501 \\
\hline Nov 09 & & 7 & 21,221 & 12,584 & -8637 \\
\hline Dec 09 & & 7 & 0 & 13,593 & 13,593 \\
\hline Jan 10 & & 7 & 0 & 12,326 & 12,326 \\
\hline Feb 10 & & 7 & 17,542 & 29,750 & 12,207 \\
\hline Mar 10 & & 6 & 46,866 & 10,628 & $-36,238$ \\
\hline Apr 10 & & 6 & 0 & 10,028 & 10,028 \\
\hline May 10 & & 6 & 60,774 & 68,706 & 7933 \\
\hline Jun 10 & & 7 & 74,064 & 56,806 & $-17,258$ \\
\hline Jul 10 & & 7 & 115,190 & 113,978 & -1212 \\
\hline Aug 10 & & 7 & 53,329 & 52,051 & -1277 \\
\hline Sep 10 & & 7 & 19,335 & 21,161 & 1826 \\
\hline Oct 10 & & 7 & 0 & 12,791 & 12,791 \\
\hline Nov 10 & & 8 & 22,691 & 14,398 & -8293 \\
\hline Dec 10 & & 7 & 21,381 & 12,371 & -9010 \\
\hline Jan 11 & & 8 & 20,711 & 13,460 & -7251 \\
\hline Feb 11 & & 9 & 22,221 & 14,529 & -7692 \\
\hline Mar 11 & & 9 & 41,872 & 59,848 & 17,975 \\
\hline Apr 11 & & 10 & 20,501 & 15,369 & -5132 \\
\hline May 11 & & 10 & 0 & 18,280 & 18,280 \\
\hline Jun 11 & & 11 & 46,321 & 38,480 & -7841 \\
\hline Jul 11 & & 13 & 44,092 & 26,624 & $-17,469$ \\
\hline Aug 11 & & 13 & 169,026 & 177,554 & 8528 \\
\hline Sep 11 & & 14 & 112,527 & 103,073 & -9455 \\
\hline Oct 11 & & 14 & 82,186 & 103,483 & 21,296 \\
\hline Nov 11 & & 14 & 43,056 & 78,413 & 35,356 \\
\hline Dec 11 & & 0 & 71,802 & 242,575 & 170,773 \\
\hline Total & 81,290 & & $1,611,624$ & $1,823,721$ & 212,092 \\
\hline
\end{tabular}

Income for Dec 11 includes the assumed sale of all long options. Prices were the bid price at the close of trading on Friday 16 Dec 2011. 
The advantage of this approach is that it enables agricultural entities to find annual funding with a single injection of funds. This should make it easier for them to raise the capital needed without repeatedly asking their members for funds. An initial investment of $\$ 4-\$ 500,000$ could be raised in an organization of 200 members with a $\$ 2000$ - \$2500 “one time injection” from each member.

This strategy produces income taxed as a capital gain which attracts half the tax load of regular taxable income in Canada.

Should an agricultural entity decide to remain with their traditional investment strategy, they would currently generate slightly above 3\% interest per year in government or corporate bonds. In the investment environment of the early $21^{\text {st }}$ century it is not expected that any increase in interest rates will likely occur of any significance for some time to come. Also, the interest would be taxed as regular income.

\section{Financial Impact on Research Expenditures}

In a scenario where a corporation spends $\$ 100,000$ for SR\&ED approved research and receives grants worth $\$ 50,000$ from a government body; the corporation could receive tax credits of $\$ 34,750$ (69.5\%) (Table 4). This is the best case as it includes the Ontario Eligible Research tax Credit. Consequently, the Corporation would need to generate $\$ 19,450$ of income to fund this research, which equals the taxes due on the income plus the net research expenditure. If the income was classed as Capital Gains, the net tax credit would be $\$ 34,750$ less the income tax of $\$ 2723(14 \%$ on $\$ 19,450)$.

The income can be generated as earned income. However, if $\$ 100,000$ were invested in the capital markets to

Table 4. Tax credit impact on research dollars invested (\$’00) within a Canadian controlled private corporation or at an eligible research Institute either from earned or invested income.

\begin{tabular}{|c|c|c|}
\hline & Within Corporation & Eligible Research Institute \\
\hline \multicolumn{3}{|l|}{ Earned Income } \\
\hline Taxable Income & 30 & 30 \\
\hline Taxes Payable-CCPC Rate 15\% & $(4.5)$ & $(4.5)$ \\
\hline Research Expenditure & $(100)$ & $(100)$ \\
\hline Grants Received & 50 & 50 \\
\hline SR\&ED Credit (35\%) & 17.5 & 17.5 \\
\hline Ontario Eligible Research Institute Tax Credit (20\%) & 0 & 10 \\
\hline Ontario Innovation Tax Credit (10\%) & 5 & 5 \\
\hline Research Tax Deduction (4.5\%) & 2.25 & 2.25 \\
\hline Net Research Expenditure & $(25.25)$ & $(15.25)$ \\
\hline Net Income & 0.25 & 10.25 \\
\hline \multicolumn{3}{|l|}{ Capital Gains } \\
\hline Taxable Capital Gains & 30 & 30 \\
\hline Taxes Payable-Capital Gain Rate 28\%/2 & $(4.2)$ & $(4.2)$ \\
\hline Research Expenditure & $(100)$ & $(100)$ \\
\hline Grants Received & 50 & 50 \\
\hline SR\&ED Credit (35\%) & 17.5 & 17.5 \\
\hline Ontario Eligible Research Institute Tax Credit (20\%) & 0 & 10 \\
\hline Ontario Innovation Tax Credit (10\%) & 5 & 5 \\
\hline Research Tax Deduction (4.5\%) & 2.25 & 2.25 \\
\hline Net Research Expenditure & $(25.25)$ & $(15.25)$ \\
\hline Net Income & 0.55 & 10.55 \\
\hline
\end{tabular}


generate a 20\%, the resulting income would cover the corporation's research costs.

Where a corporation would receive grants worth 75\% funding, as in the Growing Forward 2 program [13], the corporation's research contribution would drop to $\$ 9725$ for $\$ 100,000$ of SR\&ED approved research. This would mean that a $10 \%$ return on a $\$ 100,000$ investment would cover the corporation’s contribution.

\section{Conclusions and Recommendations}

The changing fiscal environment requires that the agrifood industry must take a larger role in directing and funding agricultural research. While governments are willing to fund a large proportion of research investments, agribusiness must find efficient ways to generate their part of the funding. This gives agricultural entities numerous research opportunities but they must find innovative long-term stable ways to generate the research funds.

In the past, small agricultural organizations have funded research out of cash flow rather than the proceeds of investments. This is the mindset that has to change. They need to develop a pool of money that can be invested so that the resulting returns are used to fund the research, not the principal.

An agricultural organization could use a for-profit corporation, to increase the pool of investors beyond those that share a common bond, as is required in a co-operative, to incorporate more easily and to ease the reporting processes that are required for a not-for-profit corporation by the Tax and Industry/Commerce ministries. The flexibility to act and revise the corporations goals are expanded in a for-profit corporation.

Properly devised, investment strategies which employ options can generate annual returns over $20 \%$. These are considered by many to be high risk. While many option strategies, such as buying calls and selling puts, are inherently high risk, strategies which employ option spreads can be designed to minimize risk. The example given here, diagonal put spread on index options, can be considered as low risk as it is protected in at least two ways: long puts, and increased volatility.

While governments have invested in agricultural research, the number of research scientists in agricultural research is declining rapidly, and succession plans are needed. For example, in 2012, the Government of Canada announced many staff cuts [14]. Therefore, both industry and government need to find ways to develop longterm succession plans to ensure that the scientists are available to provide the research the industry needs.

One possible way to ensure scientists can be employed is for governments to provide loan guarantees, for industry to invest the funds and then use the proceeds to fund research scientist positions. This is a "win-win" for both partners as governments will have access at no cost to scientists to fulfill their programs, and industry has the financial strength to fund scientists and influence the research directions to meet their needs.

While the approach suggested here is feasible and financially sound, there are details that need to be investigated further. They will vary on a case-by-case basis. They include: financial up-front costs and timing of funding, efficiencies of the options strategies, attitudes and perspectives of funding agencies (private vs. not-forprofit), the attitudes and knowledge of the investors, tax accounting for the income and investments, research structure, succession and research planning, research goals/objectives and legal issues of trust or non-profit ownership in a CCPC.

Agricultural research in Canada is at the cross-roads, and for the industry to continue to succeed it must be prepared to contribute more financially. The mix of government grants, tax credits and industry cash is considered by many to be a successful model. It is not easy for the agricultural industry to find innovative long-term stable ways to generate research funds. However, for it to succeed, the agricultural industry must learn that their contribution must come from investment strategies rather than annual cash infusions. The strategy suggested here where carefully structured options strategies, such as the diagonal put spread on index options are used, will give industry the financial returns needed to make agricultural research an inexpensive and practical investment.

Strategies similar to the one suggested here mean that a small Canadian Controlled Private Corporation (CCPC) can, for a $\$ 100,000$ up front initial investment, generate at least $\$ 100,000$ annually in research funding, in perpetuity; a viable means for the agricultural industry to fund and influence agricultural research.

\section{References}

[1] Agriculture and Agri-Food Canada (2013) 2013-14 Reports on Plans and Priorities.

[2] Agriculture and Agri-Food Canada (2013) Meta-Evaluation of Agriculture and Agri-Food Canada’s Innovation Programs (3 of 9). 
[3] University of Guelph (2013) University of Guelph-OMAFRA Agreement-2013/2014 Preliminary Budget

[4] Anonymous (1996) Agri-Food Research and Technology Transfer: Renewing the National Strategy. Canadian AgriFood Research Council, Ottawa, 32 p.

[5] Ontario Ministry of Food and Rural Affairs (2011) How Does the Ministry Set Research Priorities? Meet the OMAFRA Research Advisory Network. http://www.omafra.gov.on.ca/english/research/oran/oranindex.htm

[6] Government of Canada (2011) Canada Business Corporation Act 1985, Amended 2011.

[7] Government of Ontario (2010) Co-Operative Corporations Act, Ontario, 1990, Amended 2010.

[8] Government of Ontario (2011) Canada Not-for-Profit Corporations Act 2009, Amended 2011.

[9] Canada Revenue Agency (2015) Overview of the Scientific Research and Experimental Development (SR\&ED) Tax Incentive Program, RC442. www.cra.gc.ca/sred

[10] KPMG (2012) Are You Ready for the NEW R\&D Regime? October 25, 2012, No. 2012-33

[11] Ontario Ministry of Finance (2012) Ontario Tax Credits Available to Corporations, 2012

[12] Byrd, C. and Chen, I. (2012) Byrd \& Chen’s Canadian Tax Principles, Volume II. 2012-2013 Edition, Pearson Canada Inc., Toronto.

[13] Agriculture Adaptation Council (2013) Growing Forward 2, Capacity Building Funding Assistance for Organizations and Collaborations

[14] Public Service Alliance of Canada (2012) Cuts to Federal Science and Research Programs—Backgrounder. http://www.psac-afpc.com/issues/campaigns/3c/labs-e.shtml 